\title{
Effect of Weed Control Treatments and Planting Density in Maize (Zea mays L.)
}

\author{
E. E.A. El-Sobky and Nehal Z.A. El-Naggar
}

Agronomy Dept., Fac. Agric., Zagazig Univ., El-Sharkia, Egypt.

\begin{abstract}
7 HE PRESENT study was carried out in the Experimental Farm, Ghazala Village, Fac. Agric., Zagazig Univ., El-Sharkia Governorate, Egypt, during two successive seasons 2014 and 2015 seasons. Aim of this study find out the effect of four weed control treatments (unweeded, hand hoeing twice, Harness herbicide + hand hoeing once and Harness herbicide) and two planting densities of 24000 and 34000 plants/ $\mathrm{fad}^{\circ}$ on growth, yield and yield components of maize (Zea mays L.) (S.C. 178 yellow). According to obtained results, weed control treatments applied recorded at par higher averages of growth attributes of maize i.e. plant height $(\mathrm{cm})$, number of leaves/ plant (No.), leaves area/ plant $\left(\mathrm{cm}^{2}\right)$, leaf area index (LAI), leaves dry weight $(\mathrm{g})$ and chlorophyll content (SPAD) than unweeded one. Also, weed control treatments had significant effects on most yield and yield components due to any weeding treatments which had at par higher averages than the un-weeded control. Planting density had no significant effect on most growth attributes of maize except plant height, number of above green leaves per plant, and LAI due to increase of planting density from 24000 to 34000 plants/ fad. Densely planting (34000 plants/ fad) had significant effects on most yield and yield components except ear length $(\mathrm{cm})$, number of grains/ row (No.), number of row/ ear (No.) and harvest index (HI) while, number of ears per plant No.) was decreased. The interaction between factors had significant effects on most growth and some yield components. Application of weed control treatments was affective in depressing the competition of weeds to maize plants and hence growth and yield components of maize were improved.
\end{abstract}

Keywords: Maize, Weed control, Hoeing, Herbicide, Planting density.

Maize (Zea mays L.) is an important cereal crop which ranks the third after wheat (Triticum aestivum L.) and rice (Oryzae sativa L.). In Egypt, the total cultivated area of maize reached 1.79 millions fad, in 2014 season, produced 5.8 millions ton (FAOSTAT, 2014). Planting density plays an important role in the competitive balance between weeds and maize plants (Singh \& Singh, 2006), they recorded that high plant population affect the weeds and increased crop yield conversely, while, Teasdale (1998) did not find any significant differences between planting densities in affecting the yield. Moosavi et al. (2012) found that increasing plant density from 50000 to 140000 plants ha $^{-1}$ decreased stem diameter by $21.6 \%$ and increased plant height by $15.1 \%$, also, LAI was increased. These results are confirmed by findings of Enujeke (2013). Porter et al. (1997)

${ }^{\circ} \mathrm{fad}=4200 \mathrm{~m}^{2}$ and ha $=2.4 \mathrm{fad}$ 
reported that grain yield and $\mathrm{HI}$ were not affected by increasing plant density, however, Kumar \& Walia (2003) recorded that planting density of 90000 plants ha $^{-1}$ resulted higher LAI compared to 75000 plants $\mathrm{ha}^{-1}$. On the other hand, Acciares \& Zuluaga (2006) indicated that weeded treatments and higher planting density resulted the highest grain yield in comparison to un-weeded and lower planting density. Also, Widdicombe \& Thelen (2002) stated that yield increased up to $10 \%$ by increasing planting density. Yong et al. (2010) reported that chlorophyll content in leaves decreased with the increase of plant density.

The competition between weeds and maize for growth factors, i.e. water, light, space and nutrients reducing the quantity and quality of maize yield (Saini \& Angiras, 1998; Tamado \& Milberg, 2000 and Chikoye et al., 2004). Weeds cause significant losses reaches to 32.4 to $50 \%$ (Sharma et al., 2000), $60 \%$ (Abouziena et al., 2007) and $90 \%$ (Dalley et al., 2006). This mostly due to no or less importance given to the weeds control practices by farmers (Khaliq et al., 2004). Some researchers have reported that utilization of hand hoeing resulted an increase in maize growth, yield and its attributes (Mohamed, 2004; Sharara et al., 2005; ElMetwally et al., 2006 and Ahmed et al., 2008). Sepahvand et al. (2014) found that application of Equip herbicide + hand hoeing once gave the highest grain yield (6758 $\mathrm{kg} / \mathrm{ha}$ ). However, Ali et al. (2011) recorded that hand weeded and chemical weed control treatments gave the highest 1000-grain weight, grain and biological yields of maize. Larbi et al. (2013) indicated that using herbicides treatments resulted increases in dry matter accumulation at all development stages which contributed to maximize yield and its attributes, these observations were in agreement with Abana \& Godwin (2015) that application of herbicides significantly increased the vegetative and yield attributes of maize than of un-weeded plots. Therefore, the present research work was carried out to find out the effect of planting densities and some weed control treatments on growth and yield of maize.

\section{Material and Methods}

The present study was conducted in the experimental station (Ghazala Village), Fac. Agric., Zagazig Univ., El-Sharkia Governorate, during 2014 and 2015 seasons to find out the effect of four weed control treatments (unweeded, hand hoeing twice, Harness herbicide + hand hoeing once and Harness herbicide) and two planting densities of 24000 and 34000 plants/ fad on growth, yield and yield components of maize (Zea mays L.).

\section{Studied factors}

Weed control treatments

1. Control (un-weeded).

2. Hand hoeing twice: before the first irrigation at 21 days after planting (DAP) and second irrigation (35 DAP).

3. Harness herbicide + hand hoeing once: Harness herbicide $84 \%$ EC (2chloro-N-ethoxymethyl-6'- ethylaceto-o-toluidide) for broad and narrow leaves weeds was sprayed after planting $(1 \mathrm{~L} / \mathrm{fad})$ and before emergence (pre-emergence) followed by hand hoeing once at 35 DAP.

Egypt. J. Agron . 38, No.1 (2016) 
4. Harness herbicide. was sprayed after planting and before emergence (preemergence).

\section{Planting density}

Two planting densities were tried through varying hill spacing and number of plants per hill as followed:

1- $25 \mathrm{~cm}$ between hills leaving one plant per hill at thinning ( 24000 plants/ fad).

2- $35 \mathrm{~cm}$ between hills leaving two plants per hill at thinning (34000 plants/ fad).

To enrich the soil $\mathrm{N}$ fertility, $20 \mathrm{~kg} \mathrm{~N} / \mathrm{fad}$ was added before planting as ammonium sulphate $(20.5 \% \mathrm{~N})$. The rest $(100 \mathrm{~kg} \mathrm{~N} / \mathrm{fad})$ was split and partly added before the first irrigation (20 DAP) and second irrigation (34 DAP) as ammonium nitrate $(33.5 \% \mathrm{~N})$. A split plot design of four replications was used, where the four weed control treatments were allocated in the main plots. Whereas, planting density was allocated in sub plots $\left(17.5 \mathrm{~m}^{2}\right)$. The most broad leaves weeds present in experimental field included rough cocklebur (Xanthium strumarium L.) and purslane (Portulaca oleracea L.) and barnyard grass (Echinochloa crus-galli) and brachiaria (Brachiaria reptans) as narrow leaves weeds.

\section{Recorded data}

Maize growth and development attributes

At silking (60 DAP), plant sample of five plants was taken from the second ridge where the following data were recorded: plant height $(\mathrm{cm})$ : From soil surface up to tassel top, stem diameter $(\mathrm{cm})$ : The diameter of the $3^{\text {rd }}$ internode, number of below main ear green leaves/ plant, number of above main ear green leaves/ plant, number of total green leaves/ plant, number of dry leaves/ plant, plant leaves area $\left(\mathrm{cm}^{2}\right)$ : Leaf area was determined according to Saxena \& Singh (1965) by using blade length $\mathrm{x}$ maximum blade width $\mathrm{x} 0.75$, leaf chlorophyll content: using SPAD-502 (Castelli et al., 1996) from five guarded plants.

Leaf area index $(\mathrm{LAI})=$ Leaves area per plant / Land area per plant Specific leaf area (SLA) in $\mathrm{cm}^{2} / \mathrm{g}=$ Leaves area / Leaves dry weight per plant Specific leaf weight (SLW) in $\mathrm{g} / \mathrm{cm}^{2}=$ Leaves dry weight $/$ Leaves area per plant. These equations were used according to Watson (1958).

\section{Maize yield and yield attributes}

At harvest, (120 days from planting), the following yield components were recorded on ten plants and ears: ears number per plant, ear diameter $(\mathrm{cm})$, ear length $(\mathrm{cm})$, rows number per ear (No.), grains number per row (No.) (calculated), grains number per ear (No.), hundred grain weight (g), shelling (\%) and grain weight per ear $(\mathrm{g})$. Also, the following final yield traits were recorded from the two central rows: grain yield (ton/fad): at grain moisture content of $15.5 \%$, ears yield (ton/fad), total yield (ton/fad), stover yield (ton/fad) and harvest index (\%) i.e., grain to total yield in percentage. 
General agronomic practices

Single cross 178 maize cultivar (yellow) was planted on May $15^{\text {th }}$ in each seasons. Each sub plot $(3.5 \mathrm{~m} \times 5 \mathrm{~m})$ included 5 rows $70 \mathrm{~cm}$ apart. Seeds were hand sown in hills 25 and $35 \mathrm{~cm}$ apart on one side of the ridge. Planting was made after wheat as a preceding crop in both seasons using seeding rates of 10 $\mathrm{kg} / \mathrm{fad}$ and the plants were thinned to one plant per hill, $24000 \mathrm{plant} / \mathrm{fad}(\mathrm{D} 1)$ at two plants per hill, 34000 plant/ fad (D2) before the first irrigation (20 DAP). Phosphorus at a level of $15.5 \mathrm{~kg} \mathrm{P}_{2} \mathrm{O}_{5} /$ fad as ordinary superphosphate $(15.5 \%$ $\mathrm{P}_{2} \mathrm{O}_{5}$ ) was band placed at the time of planting. Soil samples were collected from the experimental sites at the depth of $0-30 \mathrm{~cm}$ before planting to determine soil physical and chemical properties (Central Laboratory of Faculty of Agriculture, Zagazig University, Zagazig, Egypt). The analysis of the soil showed that the soil was clay in texture having: sand $(22.63 \%)$, silt $(30.67 \%)$, clay $(46.70 \%)$, organic matter $(1.04 \%)$, total $\mathrm{N}(0.05 \%)$, available $\mathrm{P}(8.95 \mathrm{ppm})$, available $\mathrm{K}$ (148.1 ppm) and $\mathrm{pH}$ (7.99) (average of both seasons).

\section{Statistical analysis}

All obtained data were subjected to statistical analysis (ANOVA) by using MSTAT-C (1989) statistical software according to Gomez \& Gomez (1984). A combined analysis was undertaken for the data of the two seasons after testing the homogeneity of the experimental errors. Duncan Multiple range test was applied to compare the means (Duncan, 1955).

\section{Results and Discussion}

\section{Maize growth and development attributes}

Plant height $(\mathrm{cm})$ and stem diameter $(\mathrm{cm})$

Weed control effect : In the first season and combined analysis, weed control treatments had significant effect on plant height, where the weed control treatments recorded at par higher averages of plant height than un-weeded one (Table 1). However, the stem diameter was not significantly affected by weed control treatments in both seasons, but the combined analysis detected significant increase in favour of weed control treatments and over the un-weeded treatment. The increase of plant height and stem diameter due to weed control clearly indicate that, weeds in the un-weeded plots competed maize plants for plant nutrients and in particular nitrogen. The results are in accordance with those reported by Abouziena et al. (2007), Abouziena et al. (2008), Ahmed et al. (2008) and Tahir et al. (2009).

Planting density effect: Planting density was without significant effect on plant height in both seasons. However, the combined analysis detected significant increase in plant height due to the increase of planting density (Table 1). These results refer to a favorable effect caused by increasing the planting density regarding plant elongation. In the same manner, planting density was significantly affected stem girth in the first season where the increase of planting density decreased stem diameter, this effect was not observed in the second season or the combined of both seasons. Such dense planting forced plants for more elongation where plants had Egypt. J. Agron . 38, No.1 (2016) 
thinner stem diameter. These results are in agreement with those reported by Moosavi et al. (2012) and Enujeke (2013).

TABLE 1. Plant height and stem diameter of maize as affected by weed control and planting density and their interactions in both seasons and their combined analysis.

\begin{tabular}{|c|c|c|c|c|c|c|}
\hline \multirow{2}{*}{ Main effects and interactions } & \multicolumn{3}{|c|}{ Plant height (cm) } & \multicolumn{3}{|c|}{ Stem diameter (cm) } \\
\hline & 2014 & 2015 & Comb. & 2014 & 2015 & Comb. \\
\hline \multicolumn{7}{|l|}{ Weed control $(W)$} \\
\hline Un-weeded & $286.7 \mathrm{~b}$ & 279.6 & $283.1 \mathrm{~b}$ & 1.65 & 1.77 & $1.71 \mathrm{~b}$ \\
\hline Hand hoeing twice & $315.8 \mathrm{a}$ & 320.4 & $318.1 \mathrm{a}$ & 1.98 & 1.99 & $1.98 \mathrm{a}$ \\
\hline Harness $+\mathrm{H}$. hoeing once & $332.9 \mathrm{a}$ & 324.2 & $328.5 \mathrm{a}$ & 2.04 & 2.16 & $2.10 \mathrm{a}$ \\
\hline Harness herbicide & $319.8 \mathrm{a}$ & 321.3 & $320.5 \mathrm{a}$ & 2.03 & 1.95 & $1.99 \mathrm{a}$ \\
\hline F-test & $*$ & N.S & $* *$ & N.S & N.S & $*$ \\
\hline \multicolumn{7}{|l|}{ Planting density (D) } \\
\hline 24000 plants/ fad & 311.6 & 309.4 & 310.5 & 1.98 & 1.97 & 1.97 \\
\hline 34000 plants/ fad & 316.0 & 313.3 & 314.6 & 1.87 & 1.97 & 1.92 \\
\hline F-test & N.S & N.S & $*$ & $* *$ & N.S & N.S \\
\hline \multicolumn{7}{|l|}{ Interaction } \\
\hline $\mathrm{A} \times \mathrm{D}$ & N.S & $* *$ & $*(1-a)$ & $* *$ & N.S & $* *(1-b)$ \\
\hline
\end{tabular}

*** and N.S. indicate statistically significant at 0.05 and 0.01 levels and insignificancy of differences, respectively.

Interaction effect : According to the combined analysis, the plant height (Table 1- a) and stem girth (Table 1- b) were significantly affected by the weed control treatments x planting density. It is quite clear from Table 1-a that, in the un-weeded plots, the increase of planting density was followed by a significant increase in plant height. This effect was not observed in any of the weeded plots. These results are quite interesting as they indicate that, dense planting was effective to reduce the competition of weeds to maize plants. In other words, dense planting caused shading to weeds and hence might have had decreased their growth which was in favour to maize plants. It is quite clear from Table 1-b that, no particular trend could be detected regards the effect of this interaction of stem girth. However, Harness + hand hoeing once and Harness herbicide alone as well as hand hoeing twice caused to increase stem diameter under planting densities of 24000 and 34000 plants/ fad, respectively.

TABLE 1-a. Plant height of maize as affected by the weed control treatments and planting density interaction (combined data).

\begin{tabular}{|l|c|c|}
\hline \multirow{2}{*}{ Weed control } & \multicolumn{2}{|c|}{ Planting density } \\
\cline { 2 - 3 } & $\mathbf{2 4 0 0 0}$ plants/ fad & $\mathbf{3 4 0 0 0}$ plants/ fad \\
\hline \multirow{2}{*}{ Un-weeded } & $\mathrm{B}$ & $\mathrm{A}$ \\
\cline { 2 - 3 } & $276.7 \mathrm{~b}$ & $289.6 \mathrm{~b}$ \\
\hline \multirow{2}{*}{ Hand hoeing twice } & $\mathrm{A}$ & $\mathrm{A}$ \\
\hline \multirow{2}{*}{ Harness + H. hoeing once } & $315.4 \mathrm{a}$ & $320.8 \mathrm{a}$ \\
\hline \multirow{2}{*}{ Harness herbicide } & $\mathrm{A}$ & $\mathrm{A}$ \\
\cline { 2 - 3 } & $327.9 \mathrm{a}$ & $\mathrm{A}$ \\
\cline { 2 - 3 } & $\mathrm{A}$ & $319.0 \mathrm{a}$ \\
\hline
\end{tabular}

Egypt. J. Agron . 38, No. 1 (2016) 
TABLE 1-b. Stem diameter of maize as affected by the weed control treatments and planting density interaction (combined data).

\begin{tabular}{|l|c|c|}
\hline \multirow{2}{*}{ Weed control } & \multicolumn{2}{|c|}{ Planting density } \\
\cline { 2 - 3 } & $\mathbf{2 4 0 0 0}$ plants/ fad & $\mathbf{3 4 0 0 0}$ plants/ fad \\
\hline \multirow{2}{*}{ Un-weeded } & $\mathrm{A}$ & $\mathrm{A}$ \\
\cline { 2 - 3 } & $1.69 \mathrm{~b}$ & $1.73 \mathrm{~b}$ \\
\hline \multirow{2}{*}{ Hand hoeing twice } & $\mathrm{A}$ & $\mathrm{A}$ \\
\hline \multirow{2}{*}{ Harness + H. hoeing once } & $1.95 \mathrm{ab}$ & $2.02 \mathrm{a}$ \\
\hline \multirow{2}{*}{ Harness herbicide } & $\mathrm{A}$ & $\mathrm{A}$ \\
\cline { 2 - 3 } & $2.19 \mathrm{a}$ & $\mathrm{A}$ \\
\cline { 2 - 3 } & $\mathrm{A}$ & $1.92 \mathrm{ab}$ \\
\hline
\end{tabular}

\section{Number of green and dry leaves per plant}

Weed control effect: The combined analysis of both seasons detected significant increase in the number of below and above main ear green leaves per plant as well as the number of total green leaves per plant (Table 2) due to weed control treatments as compared with those recorded by the check. However, number of dry leaves per plant appeared to be increased by unweeded treatment. These results again confirm the view that, weeding treatments affected maize plants which provided better plant growth conditions due to depressing the competition of weeds to maize plants where plant nutrients were more available to these plants and hence they could keep their leaves green and delayed their senescence as expressed in their larger number below and above the main ear. These results are in agreement with those reported by Singh \& Singh (2003) and Abd El-Lattief \& Fakkar (2006). But Ahmed et al. (2008) reported that number of leaves per plant was not significantly affected by weed control treatments.

Planting density effect: In both seasons and their combined, planting density was without significant effect on the number of below or above main ear green leaves per plant as well as the number of dry leaves per plant (Table 2). However, the first season detected significant increase in number of above green leaves per plant due to increase of planting density. These results are in accordance with those reported by Enujeke (2013).

Interaction effect: None of the interaction significantly affected the number of below or above main ear green leaves per plant or the number of dry leaves per plant in both seasons and their combined. However, the weed control treatments $\mathrm{x}$ planting density interaction affected significantly the number of above main ear green leaves per plant in the second season only but, was not reflected in the combined analysis. Therefore, this interaction was not presented herein. 
EFFECT OF WEED CONTROL TREATMENTS...

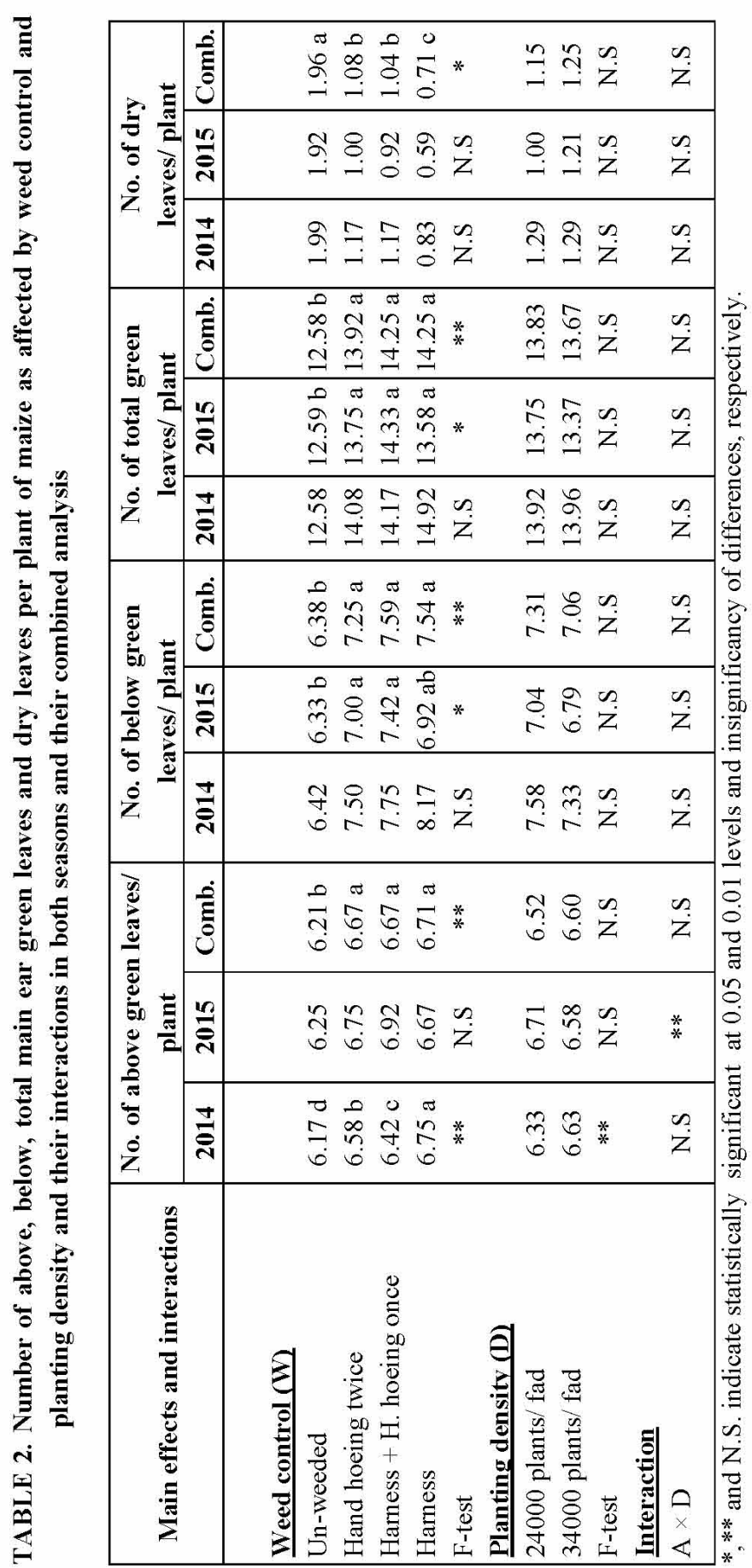

Egypt. J. Agron . 38, No. 1 (2016) 


\section{Plant leaves area, LAI, SLA and SLW per plant}

Weed control effect: In both seasons and their combined, weed control treatments had significant effects on plant leaves area and hence leaf area index. However, weed control treatments did not significantly affect any of the specific leaf attributes in both seasons and their combined as shown in Table 3. These results are in accordance with those reported by Singh \& Singh (2003) and Abd El-Lattief \& Fakkar (2006).

Planting density effect: In both seasons and their combined analysis a significant increase could be detected in LAI due to the increase of the planting density (Table 3). Otherwise, planting density was without significant effect on the plant leaves area, specific leaf area and specific leaf weight. The increase of LAI due to the increase of planting density could be attributed to the increase of the number of plants per unit area due to the increase of the number of plants per hill. The increase of planting density did not significantly decrease leaves area per plant. Therefore, LAI was certainly increase when the number of plants per hill was increase. These results are in agreement with those reported by Kumar \& Walia (2003) and Moosavi et al. (2012).

Interaction effect: The SLA was significantly affected by the weed control treatments $x$ planting density interaction in the two seasons and their combined analysis (Table 3-a). Also, the weed control treatments x planting density interaction affected significantly the plant leaves area in the first season only. In the unweeded plots, the increase of planting density resulted in a significant increase in SLA. The reverse was true regarding the hand hoeing treatment, in the other two weed control treatments, SLA was not affected by varying the planting density.

\section{Leaves dry weight per plant and chlorophyll content}

Weed control effect: The combined analysis of both seasons detected significant increase in the leaves dry weight per plant as well as the chlorophyll content due to the weed control treatments compared with that recorded by the check. However, weed control treatments had at par leaves dry weight averages and as well as leaf chlorophyll content in both seasons (Table 4). These results are rather excepted as weeding was effective to increase the number of leaves per plant (Table 2). These results are in agreement with those reported by Ahmed et al. (2008). 
EFFECT OF WEED CONTROL TREATMENTS...

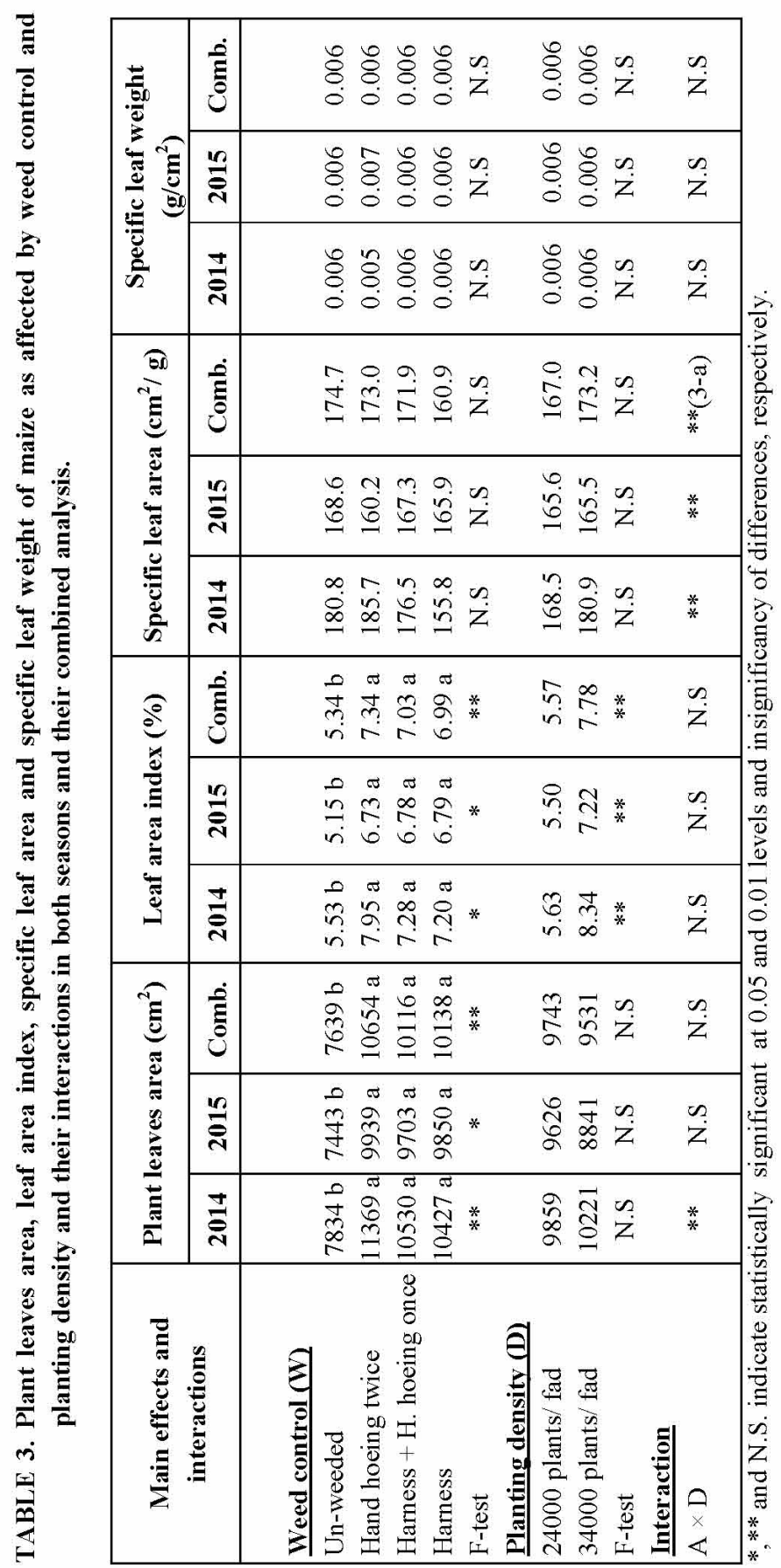

Egypt. J. Agron . 38, No. 1 (2016) 
TABLE (3-a). Specific leaf area of maize as affected by the weed control treatments and planting density interaction (combined data).

\begin{tabular}{|c|c|c|}
\hline \multirow{2}{*}{ Weed control } & \multicolumn{2}{|c|}{ Planting density } \\
\hline & 24000 plants/ fad & 34000 plants/ fad \\
\hline \multirow{2}{*}{ Un-weeded } & $\mathrm{B}$ & A \\
\hline & $151.8 \mathrm{~b}$ & $197.6 \mathrm{a}$ \\
\hline \multirow{2}{*}{ Hand hoeing twice } & $\mathrm{A}$ & $\mathrm{B}$ \\
\hline & $191.8 \mathrm{a}$ & $154.2 \mathrm{~b}$ \\
\hline \multirow{2}{*}{ Harness $+\mathrm{H}$. hoeing once } & $\mathrm{A}$ & $\mathrm{A}$ \\
\hline & $159.1 \mathrm{ab}$ & $184.7 \mathrm{ab}$ \\
\hline \multirow{2}{*}{ Harness } & $\mathrm{A}$ & $\mathrm{A}$ \\
\hline & $165.5 \mathrm{ab}$ & $156.2 \mathrm{ab}$ \\
\hline
\end{tabular}

TABLE 4. leaves dry weight per plant and chlorophyll content of maize as affected by weed control and planting density and their interactions in both seasons and their combined analysis.

\begin{tabular}{|c|c|c|c|c|c|c|}
\hline \multirow{2}{*}{$\begin{array}{l}\text { Main effects and } \\
\text { interactions }\end{array}$} & \multicolumn{3}{|c|}{ Leaves dry weight/ plant (g) } & \multicolumn{3}{|c|}{$\begin{array}{l}\text { Chlorophyll content } \\
\text { (SPAD values) }\end{array}$} \\
\hline & 2014 & 2015 & Comb. & 2014 & 2015 & Comb. \\
\hline \multicolumn{7}{|l|}{$\underline{\text { Weed control }(W)}$} \\
\hline Un-weeded & 46.32 & 44.67 & $45.49 \mathrm{~b}$ & 39.30 & 43.50 & $41.40 \mathrm{~b}$ \\
\hline Hand hoeing twice & 61.53 & 63.15 & $62.34 \mathrm{a}$ & 45.13 & 46.73 & $45.93 \mathrm{ab}$ \\
\hline Harness $+\mathrm{H}$. hoeing once & 59.95 & 58.76 & $59.35 \mathrm{a}$ & 50.48 & 50.28 & $50.38 \mathrm{a}$ \\
\hline Harness & 66.95 & 59.71 & $63.33 \mathrm{a}$ & 45.48 & 49.88 & $47.68 \mathrm{a}$ \\
\hline F-test & N.S & N.S & $* *$ & N.S & N.S & $* *$ \\
\hline \multicolumn{7}{|l|}{ Planting density (D) } \\
\hline 24000 plants/ fad & 58.91 & 57.95 & 58.43 & 44.94 & 49.35 & 47.14 \\
\hline 34000 plants/ fad & 58.46 & 55.19 & 56.83 & 45.25 & 45.84 & 45.54 \\
\hline F-test & N.S & N.S & N.S & N.S & $* *$ & $* *$ \\
\hline \multicolumn{7}{|l|}{ Interaction } \\
\hline $\mathrm{A} \times \mathrm{D}$ & $* *$ & $* *$ & $* *(4-a)$ & $* *$ & $* *$ & $* *(4-b)$ \\
\hline
\end{tabular}

Planting density effect: In both seasons and their combined, planting density was without significant effect on the leaves dry weight per plant (Table 4). However, in the second season and combined analysis detected significant decrease in chlorophyll content due to increase of planting density. These results clearly indicate that, dense sown maize plants might have had suffered from paleness where leaves were less green and hence performed less regarding their photosynthesis. This could paleness could be attributed to the sufficient increase of LAI which resulted from the increase of planting density and hence the possible increase of mutual shading. This dense planting forced plants for more elongation where plants had thinner stem diameter in the first season (Table 1). These results are in accordance with those reported by Yong et al. (2010).

Egypt. J. Agron . 38, No.1 (2016) 
Interaction effect: Results in Table 4-a clearly indicate that, dense planting in the unweeded plots caused a decrease which was about to reach significance in leaves dry weight per plant. On the other hand, a significant increase in the hand weeded ones this refer to better plant growth due to dense planting when weeds were controlled and hence their competition was decreased. Reference to Table 1-a about the effect of the interaction on plant height indicate a significant increase in plant elongation due to dense planting in the un-weeded plots. The increase of chlorophyll content of these plants observed herein in Table 4-b might refer to better weed plant inter species competition due to dense planting in the un-weeded plots caused by the increase of their leaves chlorophyll content. This effect was not observed in the twice hand weeded plots as maize plants did not suffer from any weed inter plant competition and hence dense planting did not add any advantage to maize plants regarding their leaves content from chlorophyll.

TABLE 4-a. Leaves dry weight/ plant of maize as affected by the weed control treatments and planting density interaction (combined data).

\begin{tabular}{|c|c|c|}
\hline \multirow{2}{*}{ Weed control } & \multicolumn{2}{|c|}{ Planting density } \\
\hline & 24000 plants/ fad & 34000 plants/ fad \\
\hline \multirow{2}{*}{ Un-weeded } & $\mathrm{A}$ & $\mathrm{A}$ \\
\hline & $48.80 \mathrm{~b}$ & $42.19 \mathrm{~b}$ \\
\hline \multirow{2}{*}{ Hand hoeing twice } & $\mathrm{B}$ & $\mathrm{A}$ \\
\hline & $57.95 \mathrm{ab}$ & $66.73 \mathrm{a}$ \\
\hline \multirow{2}{*}{ Harness $+\mathrm{H}$. hoeing once } & $\mathrm{A}$ & $\mathrm{B}$ \\
\hline & $63.32 \mathrm{a}$ & $55.39 \mathrm{a}$ \\
\hline \multirow{2}{*}{ Harness } & $\mathrm{A}$ & $\mathrm{A}$ \\
\hline & $63.64 \mathrm{a}$ & $63.01 \mathrm{a}$ \\
\hline
\end{tabular}

TABLE 4-b. Chlorophyll content of maize as affected by the weed control treatments and planting density interaction (combined data).

\begin{tabular}{|l|c|c|}
\hline \multirow{2}{*}{ Weed control } & \multicolumn{2}{|c|}{ Planting density } \\
\cline { 2 - 3 } & $\mathbf{2 4 0 0 0}$ plants/ fad & $\mathbf{3 4 0 0 0}$ plants/ fad \\
\hline \multirow{2}{*}{ Un-weeded } & $\mathrm{B}$ & $\mathrm{A}$ \\
\hline \multirow{2}{*}{ Hand hoeing twice } & $37.85 \mathrm{~b}$ & $44.95 \mathrm{a}$ \\
\hline \multirow{2}{*}{ Harness + H. hoeing once } & $\mathrm{A}$ & $\mathrm{A}$ \\
\cline { 2 - 3 } & $47.48 \mathrm{a}$ & $44.38 \mathrm{a}$ \\
\hline \multirow{2}{*}{ Harness } & $\mathrm{A}$ & $\mathrm{B}$ \\
\cline { 2 - 3 } & $53.60 \mathrm{a}$ & $47.15 \mathrm{a}$ \\
\cline { 2 - 3 } & $\mathrm{A}$ & $\mathrm{A}$ \\
\hline
\end{tabular}


Maize yield and yield components

Weed control effect

It is evident from Tables 5 and 6 that, weed control treatments were without significant effect on most grain yield attributes except ear diameter $(\mathrm{cm})$ and grain number per row ((No.) as detected from the combined analysis of the two seasons. Both grain yield components were increased significantly due to weeding without significant differences among the three weeding treatments which recorded at par higher averages than the un-weeded control. These results refer to a compensation to the retarded growth of maize plants in the un-weeded plots which was expressed in shortness of maize plants in two seasons and their combined and stem diameter according to the combined analysis (Table 1).

TABLE 5. Ear length, ear diameter and ear number per plant of maize as affected by weed control and planting density and their interactions in both seasons and their combined analysis.

\begin{tabular}{|c|c|c|c|c|c|c|c|c|c|}
\hline \multirow{2}{*}{ Main effects and interactions } & \multicolumn{3}{|c|}{ Ear length $(\mathrm{cm})$} & \multicolumn{3}{|c|}{ Ear diameter $(\mathrm{cm})$} & \multicolumn{3}{|c|}{ No. of ears / plant } \\
\hline & 2014 & 2015 & Comb. & 2014 & 2015 & Comb. & 2014 & 2015 & Comb. \\
\hline \multicolumn{10}{|l|}{ Weed control $(\mathbf{W})$} \\
\hline$\overline{\text { Un-weeded }}$ & 17.80 & 17.78 & 17.79 & 4.39 & 4.48 & $4.43 \mathrm{~b}$ & $1.06 \mathrm{~b}$ & 1.15 & 1.10 \\
\hline Hand hoeing twice & 19.17 & 19.88 & 19.51 & 4.72 & 4.73 & $4.73 \mathrm{a}$ & $1.09 \mathrm{~b}$ & 1.11 & 1.10 \\
\hline Harness $+\mathrm{H}$. hoeing once & 19.19 & 20.05 & 19.62 & 4.76 & 4.73 & $4.74 \mathrm{a}$ & $1.16 \mathrm{a}$ & 1.15 & 1.15 \\
\hline Harness herbicide & 20.25 & 20.23 & 20.24 & 4.80 & 4.81 & $4.80 \mathrm{a}$ & $1.16 \mathrm{a}$ & 1.10 & 1.13 \\
\hline F-test & N.S & N.S & N.S & N.S & N.S & $* *$ & $*$ & N.S & N.S \\
\hline \multicolumn{10}{|l|}{ Planting density (D) } \\
\hline 24000 plants/ fad & 19.27 & 19.44 & 19.35 & 4.63 & 4.64 & 4.64 & 1.21 & 1.20 & 1.20 \\
\hline 34000 plants/ fad & 18.93 & 19.53 & 19.23 & 4.70 & 4.73 & 4.72 & 1.03 & 1.05 & 1.04 \\
\hline F-test & N.S & N.S & N.S & N.S & $*$ & $*$ & $* *$ & $* *$ & $* *$ \\
\hline \multicolumn{10}{|l|}{ Interaction } \\
\hline $\mathrm{A} \times \mathrm{D}$ & N.S & *** & $* *(5-a)$ & N.S & N.S & $* *(5-b)$ & N.S & N.S & N.S \\
\hline
\end{tabular}

TABLE 6. Grain number per row, row number per ear and grain number per ear of maize as affected by weed control and planting density and their interactions in both seasons and their combined analysis.

\begin{tabular}{|l|c|c|c|c|c|c|c|c|c|}
\hline \multirow{2}{*}{$\begin{array}{l}\text { Main effects and } \\
\text { interactions }\end{array}$} & \multicolumn{2}{|c|}{ Grain number/ row } & \multicolumn{3}{|l|}{ Row number/ ear } & \multicolumn{3}{|c|}{ Grain number/ ear } \\
\cline { 2 - 10 } & $\mathbf{2 0 1 4}$ & $\mathbf{2 0 1 5}$ & Comb. & $\mathbf{2 0 1 4}$ & $\mathbf{2 0 1 5}$ & Comb. & $\mathbf{2 0 1 4}$ & $\mathbf{2 0 1 5}$ & Comb. \\
\hline Weed control (W) & & & & & & & & & \\
Un-weeded & 36.15 & 36.30 & $36.23 b$ & 14.50 & 14.60 & 14.55 & 531.1 & 534.5 & 532.8 \\
Hand hoeing twice & 38.50 & 37.80 & $38.15 \mathrm{ab}$ & 15.00 & 14.90 & 14.95 & 575.7 & 563.2 & 569.5 \\
Harness + H. hoeing once & 39.65 & 40.55 & $40.10 \mathrm{a}$ & 15.10 & 14.50 & 14.80 & 598.1 & 585.4 & 591.8 \\
Harness herbicide & 40.40 & 39.50 & 39.95 & 14.50 & 15.10 & 14.80 & 584.7 & 594.2 & 589.5 \\
F-test & N.S & N.S & $*$ & N.S & N.S & N.S & N.S & N.S & N.S \\
Planting density (D) & & & & & & & & & \\
24000 plants/ fad & 38.60 & 38.63 & 38.61 & 14.95 & 14.30 & 14.63 & 577.7 & 553.9 & 565.8 \\
34000 plants/ fad & 38.75 & 38.45 & 38.60 & 14.60 & 15.25 & 14.93 & 567.1 & 584.8 & 576.0 \\
F-test & N.S & N.S & N.S & N.S & N.S & N.S & N.S & $* *$ & N.S \\
Interaction & & & & & & & & & \\
A $\times$ D & N.S & $* *$ & N.S & N.S & N.S & N.S & N.S & N.S & N.S \\
\hline
\end{tabular}

*,** and N.S. indicate statistically significant at 0.05 and 0.01 levels and insignificancy of differences, respectively.

Egypt. J. Agron . 38, No.1 (2016) 
These adverse effects were not reflected in any of the yield components. These results are in agreement with those reported by Douan et al. (2004), Sharara et al. (2005), Abouziena et al. (2007), Tahir et al. (2009), Larbi et al. (2013) and Sepahvand et al. (2014). But, Ahmed et al. (2008) indicated that ear length and number of grains per row significantly increased by weed control treatments and both ear diameter and number of rows per ear were not significantly affected by different weed control treatments. Amare et al. (2014) showed that ear number per plant was significantly affected by weed control methods where the highest number of ears per plant was observed in hand weeding and hoeing.

\section{Planting density effect}

Planting density was without significant effect on most grain yield attributes (Tables 5 and 6) except ear diameter and the number of ears per plant where, in the second season and combined analysis detected significant increase in ear diameter due to increase of planting density. Although, in both seasons and the combined analysis detected significant decrease in the number of ears per plant due to dense planting. The decrease of the number of ears per plant due to the increase of planting density could be attributed to reducing intraspecific competition among maize plants. Abouziena et al. (2008) and El-Shahed et al. (2013) reported that the highest average of ear length and the grain number per ear were recorded at low plant population.

\section{Interaction effect}

According to the combined analysis, ear length Table 5-a and ear diameter Table 5-b were significantly affected by the weed control treatments x planting density. It is quite clear from Table 5-a that dense planting in un-weeded plots caused a decrease in ear length, which probably due to the both interspecific and intraspecific competitions. On the other hand, with hand hoeing twice treatment increasing planting density followed by a significant increase in ear length, this refers to better dry matter accumulation under dense planting when weeds were controlled and their competition was decreased. It is evident from Table 5-b that in the un-weeded plots the increase of planting density was followed by a significant increase in ear diameter. This effect was not observed in any of the weeded plots, which indicated that dense planting effectively decreased the competition between weeds and maize plants.

TABLE 5-a. Ear length (cm) of maize as affected by weed control treatments and the planting density interaction (combined data).

\begin{tabular}{|l|c|c|}
\hline \multirow{2}{*}{ Weed control } & \multicolumn{2}{|c|}{ Planting density } \\
\cline { 2 - 3 } & $\mathbf{2 4 0 0 0}$ plants/ fad & $\mathbf{3 4 0 0 0}$ plants/ fad \\
\hline \multirow{2}{*}{ Un-weeded } & $\mathrm{A}$ & $\mathrm{A}$ \\
\cline { 2 - 3 } & $17.78 \mathrm{~b}$ & $17.80 \mathrm{~b}$ \\
\hline \multirow{2}{*}{ Hand hoeing twice } & $\mathrm{B}$ & $\mathrm{A}$ \\
\hline \multirow{2}{*}{ Harness + H. hoeing once } & $18.95 \mathrm{ab}$ & $20.08 \mathrm{a}$ \\
\cline { 2 - 3 } & $\mathrm{A}$ & $\mathrm{B}$ \\
\hline \multirow{2}{*}{ Harness } & $20.29 \mathrm{ab}$ & $18.95 \mathrm{ab}$ \\
\cline { 2 - 3 } & $\mathrm{A}$ & $\mathrm{A}$ \\
\hline
\end{tabular}

Egypt. J. Agron. 38, No. 1 (2016) 
TABLE 5-b. Ear diameter (cm) of maize as affected by weed control treatments and the planting density interaction (combined data).

\begin{tabular}{|l|c|c|}
\hline \multirow{2}{*}{\multicolumn{1}{|c}{ Weed control }} & \multicolumn{2}{|c|}{ Planting density } \\
\cline { 2 - 3 } & $\mathbf{2 4 0 0 0}$ plants/ fad & $\mathbf{3 4 0 0 0}$ plants/ fad \\
\hline \multirow{2}{*}{ Un-weeded } & $\mathrm{B}$ & $\mathrm{A}$ \\
\hline \multirow{2}{*}{ Hand hoeing twice } & $4.32 \mathrm{~b}$ & $4.55 \mathrm{a}$ \\
\hline \multirow{2}{*}{ Harness + H. hoeing once } & $\mathrm{A}$ & $\mathrm{A}$ \\
\cline { 2 - 3 } & $4.65 \mathrm{a}$ & $4.80 \mathrm{a}$ \\
\hline \multirow{2}{*}{ Harness } & $\mathrm{A}$ & $\mathrm{A}$ \\
\hline
\end{tabular}

Weed control effect

It is evident from Tables 7 and 8 that, weed control treatments had significant effects on most yield and yield attributes due to any weeding treatments applied which had at par higher averages than the un-weeded control. The combined analysis detected significant increase in grain weight per ear due to weeding treatments. Such increase probably could be attributed to the increase in seed index as the grain number per row forementioned and observed in Table 6 according to the combined analysis. But, did not reflect similar increase in the grain number per ear (No.) which was not significantly affected.

The hand hoeing once with using Harness herbicide as a weed control treatment had increased the grain weight per ear and grain yield per fad by 34.68 and $68.45 \%$ in comparison with un-weeded treatment. Likewise, utilization of Harness herbicide led to an increase in 100-grain weight and shelling $\%$ by 15.85 and $3.23 \%$, respectively. Therefore, the increase of grain weight per ear is resultant of the increase of single grain weight rather than grain number per ear. Therefore, any growth improvement due to weeding was reflected late in the season during grain filling rather than grain set. Also, similar significant effects were observed in shelling percentage, ears, stover and total yields per fad as well as harvest index where, they were increased significantly due to weeding without significant differences among the three weeding treatments which recorded at par higher averages than the un-weeded control. These results are in agreement with those obtained by El-Metwally et al. (2001), Dalley et al. (2006), Abouziena et al. (2008), Ali et al. (2011), Larbi et al. (2013), Zhang et al. (2013), Amare et al. (2014), Sepahvand et al. (2014), Williams et al. (2014) and Abana \& Godwin (2015).

Egypt. J. Agron . 38, No.1 (2016) 
EFFECT OF WEED CONTROL TREATMENTS...

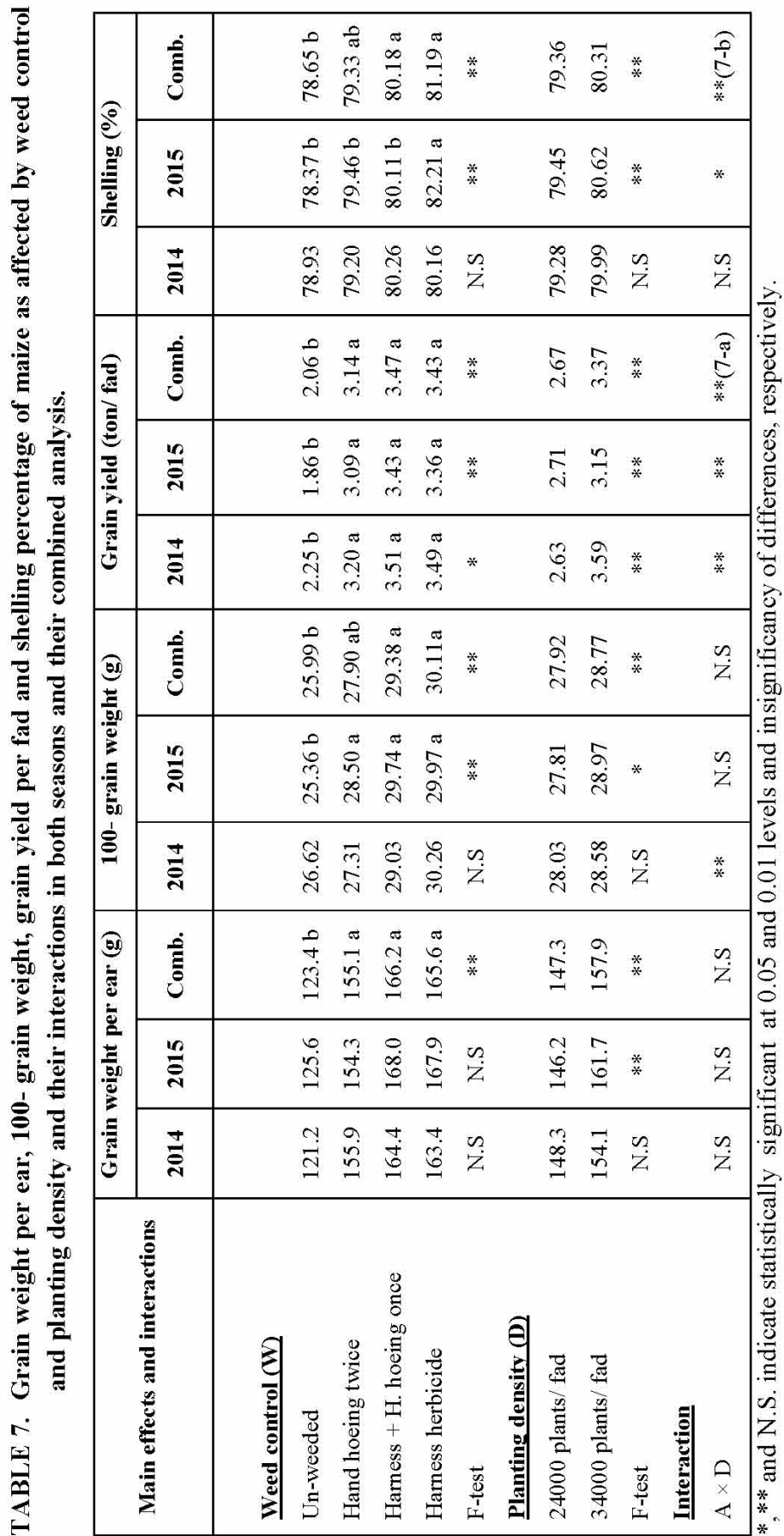

Egypt. J. Agron . 38, No. 1 (2016) 


\begin{tabular}{|c|c|c|c|c|}
\hline \multirow{3}{*}{ 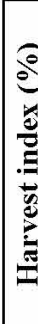 } & $\dot{\vec{E}}$ & 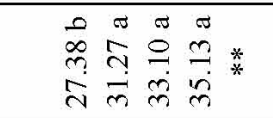 & 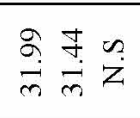 & $\begin{array}{l}\sim_{2} \\
z\end{array}$ \\
\hline & 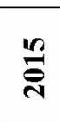 & 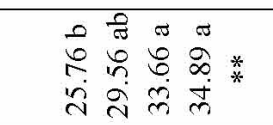 & 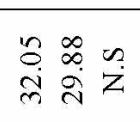 & $\stackrel{n}{z}$ \\
\hline & ज্ & 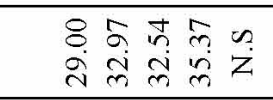 & 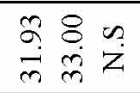 & $\stackrel{n}{n}$ \\
\hline : & $\dot{\vec{E}}$ & 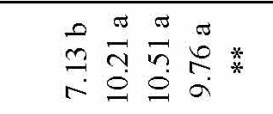 & $\overbrace{\infty} \stackrel{\infty}{\stackrel{n}{\circ}}$ & $\begin{array}{l}n \\
z\end{array}$ \\
\hline 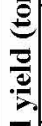 & 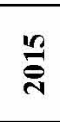 & 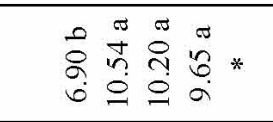 & 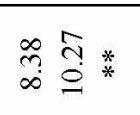 & 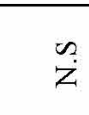 \\
\hline 吾 & $\overrightarrow{\bar{N}}$ & 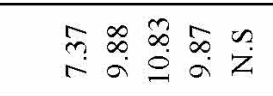 & 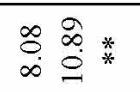 & $\stackrel{n}{Z}$ \\
\hline : & $\dot{\vec{E}}$ & 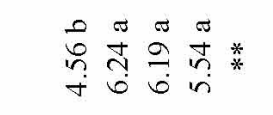 & 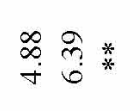 & $\stackrel{n}{z}$ \\
\hline 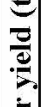 & $\frac{\text { N }}{\bar{N}}$ & 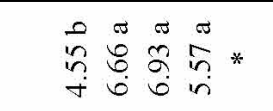 & 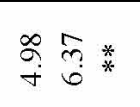 & $\stackrel{\infty}{z}$ \\
\hline 它 & $\overrightarrow{\bar{N}}$ & 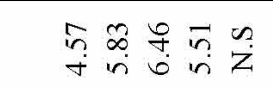 & 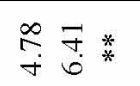 & $\stackrel{\sim}{z}$ \\
\hline छ & $\dot{\vec{E}}$ & 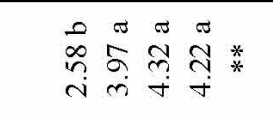 & $\stackrel{m}{\dot{m}} \stackrel{\vartheta}{F} *$ & 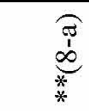 \\
\hline $\begin{array}{l}\frac{8}{3} \\
\frac{\pi}{2} \\
\frac{\pi}{2}\end{array}$ & 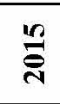 & 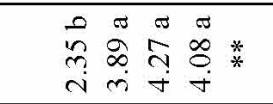 & ले & * \\
\hline 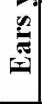 & $\overrightarrow{\bar{N}}$ & 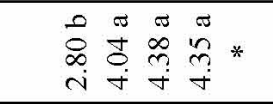 & 怘 & * \\
\hline & 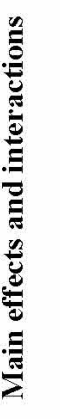 & 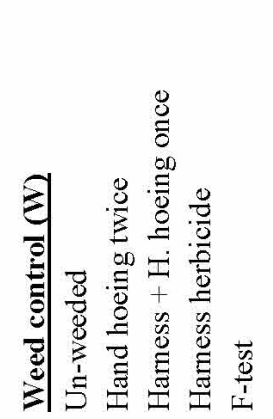 & 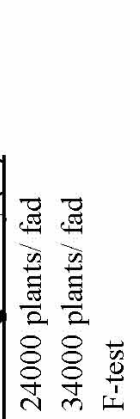 & 氧总 \\
\hline
\end{tabular}

Egypt. J. Agron . 38, No.1 (2016) 
Planting density effect

Results in Tables 7 and Table 8 clearly indicate that, planting density had significant effect on most grain yield and yield attributes except the HI. Where dense planting treatment recorded the higher averages of the former traits than the lower density. The increase of planting density caused the higher averages of grain weight/ ear, 100- grain weight, grain yield/ fad and shelling \% by $7.20,3.04,26.22$ and $1.20 \%$, respectively in comparison to the lower planting density. In the combined analysis detected significant increase in grain weight per ear due to dense planting which could be attributed to the increase in seed index and reflect similar increase in grain yield per fad which was significantly affected. Also, dense planting increased ears, stover and total yields by $25.07,30.94$ and $28.55 \%$, respectively. These results are in agreement with those reported by other investigators of them Porter et al. (1997), Bavec \& Bavec (2002), Widdicombe \&Thelen (2002), Acciares \& Zuluaga (2006), Maddonni et al. (2006), Singh \& Singh (2006) and Williams et al. (2014). But, Abouziena et al. (2008) found that the highest 100- grain weight and grain weight/ ear were recorded when maize was planted with low plant population. However, in both seasons and their combined, planting density was without significant effect on HI. These results are in harmony with those obtained by Shapiro \& Wortmann (2006) who reported that planting densities were without significant effect on HI.

\section{Interaction effect}

According to the combined analysis, grain yield per fad (Table 7- a) and shelling \% (Table 7- b) and ears yield per fad (Table 8-a) were significantly affected by the weed control treatments x planting density. As general, results in Table 7- a concluded that under un-weeded and all weed control treatments increase planting density trended to be significantly increased grain yield/ fad. This supports the view of dense planting decreased the competition between weeds and maize plants which clearly manifested in grain yield. The highest grain yield per fad (4.02 ton) was achieved by Harness herbicide when dense planting of 34000 plants per fad. Otherwise, the lowest grain yield per fad (1.84 ton) was recoded by unweeded treatment when light planting density of 24000 plants per fad. It is evident from Table 7- $\mathrm{b}$ that increasing planting density in un-weeded plots led to a significant increase in shelling percentage. This effect did not observe in any of the weeded plots. These results clearly explained the increase in grain yield per fad due to increasing planting density. It is evident from Table 8-a that increasing planting density followed by a respective significant increase in ear yield/ fad for all un-weeded and weeded plots which was in favour to maize grain yield/fad. On the other hand, the highest ears yield per fad (4.91 ton) was recoded by Harness herbicide when dense planting of 34000 plants per fad. Otherwise, the lowest grain yield per fad ( 2.33 ton) was recoded by unweeded treatment when light planting density of 24000 plants per fad. 
TABLE 7-a. Grain yield (ton/ fad) of maize as affected by weed control treatments and the planting density interaction (combined data).

\begin{tabular}{|l|c|c|}
\hline \multirow{2}{*}{ Weed control } & \multicolumn{2}{|c|}{ Planting density } \\
\cline { 2 - 3 } & $\mathbf{2 4 0 0 0}$ plants/ fad & $\mathbf{3 4 0 0 0}$ plants/ fad \\
\hline \multirow{2}{*}{ Un-weeded } & $\mathrm{B}$ & $\mathrm{A}$ \\
\cline { 2 - 3 } & $1.84 \mathrm{~b}$ & $2.27 \mathrm{~b}$ \\
\hline \multirow{2}{*}{ Hand hoeing twice } & $\mathrm{B}$ & $\mathrm{A}$ \\
\hline \multirow{2}{*}{ Harness + H. hoeing once } & $2.80 \mathrm{a}$ & $3.49 \mathrm{a}$ \\
\cline { 2 - 3 } & $\mathrm{B}$ & $\mathrm{A}$ \\
\hline \multirow{2}{*}{ Harness } & $3.23 \mathrm{a}$ & $3.71 \mathrm{a}$ \\
\cline { 2 - 3 } & $\mathrm{B}$ & $\mathrm{A}$ \\
\hline
\end{tabular}

TABLE 7-b. Shelling percentage of maize as affected by weed control treatments and the planting density interaction (combined data).

\begin{tabular}{|l|c|c|}
\hline \multirow{2}{*}{\multicolumn{1}{|c}{ Weed control }} & \multicolumn{2}{|c|}{ Planting density } \\
\cline { 2 - 3 } & $\mathbf{2 4 0 0 0}$ plants/ fad & $\mathbf{3 4 0 0 0}$ plants/ fad \\
\hline \multirow{2}{*}{ Un-weeded } & $\mathrm{B}$ & $\mathrm{A}$ \\
\cline { 2 - 3 } & $77.52 \mathrm{~b}$ & $79.78 \mathrm{~b}$ \\
\hline \multirow{2}{*}{ Hand hoeing twice } & $\mathrm{A}$ & $\mathrm{A}$ \\
\hline \multirow{2}{*}{ Harness + H. hoeing once } & $79.58 \mathrm{a}$ & $79.07 \mathrm{~b}$ \\
\cline { 2 - 3 } & $\mathrm{A}$ & $\mathrm{A}$ \\
\hline \multirow{2}{*}{ Harness } & $80.03 \mathrm{a}$ & $\mathrm{A}$ \\
\cline { 2 - 3 } & $80.34 \mathrm{~b}$ \\
\cline { 2 - 3 } & $\mathrm{A}$ & $82.04 \mathrm{a}$ \\
\hline
\end{tabular}

TABLE 8-a. Ears yield (ton/ fad) of maize as affected by weed control treatments and the planting density interaction (combined data).

\begin{tabular}{|l|c|c|}
\hline \multirow{2}{*}{\multicolumn{1}{|c}{ Weed control }} & \multicolumn{2}{|c|}{ Planting density } \\
\cline { 2 - 3 } & $\mathbf{2 4 0 0 0}$ plants/ fad & $\mathbf{3 4 0 0 0}$ plants/ fad \\
\hline \multirow{2}{*}{ Un-weeded } & $\mathrm{B}$ & $\mathrm{A}$ \\
\hline \multirow{2}{*}{ Hand hoeing twice } & $2.33 \mathrm{~b}$ & $2.83 \mathrm{~b}$ \\
\hline \multirow{2}{*}{ Harness + H. hoeing once } & $\mathrm{B}$ & $\mathrm{A}$ \\
\cline { 2 - 3 } & $3.52 \mathrm{a}$ & $4.42 \mathrm{a}$ \\
\hline \multirow{2}{*}{ Harness } & $\mathrm{B}$ & $\mathrm{A}$ \\
\hline
\end{tabular}

Egypt. J. Agron . 38, No.1 (2016) 


\section{References}

Abana, P. C. and Godwin, O. (2015) Screening of selected herbicides for weed control in maize Zea mays L. J. Environ. and Earth Sci. 5 (2), 53-56.

Abd El-Lattief, E.A. and Fakkar, A.A.O. (2006) Growth, yield and yield components of maize (Zea mays L.) as influenced by nitrogen fertilization levels and mechanical weed control treatments. J. Agric. Sci. Mansoura Univ. 31 (12), 7485-7496.

Abouziena, H. F., El-Karmany M. F., Singh, M. and Sharma, S. D. (2007) Effect of nitrogen rates and weed control treatment on maize yield and associated weeds in sandy soils. Weed Techn. 21, 1049-1053.

Abouziena, H.F., El-Metwally, I.M. and El-Desoki, E.R. (2008) Effect of plant spacing and weed control treatments on maize yield and associated weeds in sandy soils. AmEuras. J. Agric. and Environ. Sci. 4 (1), 09-17.

Acciares, H. A. and Zuluaga, M. S. (2006) Effect of plant row spacing and herbicide use on weed aboveground biomass and corn grain yield. Planta Daninha, 24 (2), 287-293.

Ahmed, S.A., Shams, H.M., El-Metwally, I.M., Shehata, M.N. and El-Wakeel, Mona A. (2008) Efficiency of some weed control treatments on growth, yield and its attributes of maize (Zea mays, L.) plants and associated weeds. J. Agric. Mansoura Univ. 33 (7), 4777-4789.

Ali, K., Munsif, F., Husain, Z., Khan, I., Ahmed, N., Khan, N. and Shahid, M. (2011) Effect of different weed control methods on weeds and maize grain yield. Pak. J. Weed Sci. Res. 17 (4), 313-321.

Amare, T., Mohammed, A., Negeri, M. and Sileshi, F. (2014) Effect of weed control methods on weed density and maize (Zea mays L.) yield in West Shewa Orimia, Ethiopia. African J. Plant Sci. 8 (12), 528-536.

Bavec, F. and Bavec, M. (2002) Effect of plant population on leaf area index, cob characteristics and grain yield of early maturing maize cultivars (FAO 100-400). Euro. J. Agron. 16, 151-159.

Castelli, F., Contillo, R. and Miceli, F. (1996)Non-destructive determination of leaf chlorophyll content in four crop species. J. Agron. and Crop Sci. 177, 275-283.

Chikoye, D., Schulza, S. and Ekeleme, F. (2004) Evaluation of integrated weed management practices for maize in the northern Guinea savanna of Nigeria. Crop Prot. 23, 895-900. 
Dalley, C. D., Bernards, M. L. and Kells, J. J. (2006) Effect of weed removal timing and row spacing on soil moisture in corn (Zea mays). Weed Techol. 20, 399-409.

Douan, M. N., Nay, A., Boz, Z. and Albay, F. (2004) Determination of optimum weed control timing in maize (Zea mays L.). Turk. J. Agric., 28, 349-354.

Duncan, D.B. (1955) Multiple range and multiple "F" test. Biometrics, 11, 1-42.

El-Metwally, I.M., Ahmed, S.A. and Saad El-Din, Samia A. (2001) Nitrogen fertilizer levels and some weed control treatments effects on maize and its associated weeds. $J$. Agric. Sci. Mansoura Univ. 26 (2), 585- 601.

El-Metwally, I. M., Abd EI Razik, M. R. and Zain El Din, M. M. (2006) Effect some weed control treatments on growth, yield, yield attributes, some seed technological characters of maize plants and it's associated weeds. J. Agric. Sci. Mansoura Univ. 31 (7), 4259-4270.

El-Shahed, H.M., Saleh, M.E., Mowafy, S.A. and Osman, M.M.A. (2013) Effect of planting density and skipping irrigation at certain growth stages on yield potentiality of some maize hybrids. Zagazig J. Agric. Res. 40 (4), 617-646.

Enujeke, E.C. (2013) Effect of variety and spacing on growth characters of hybrid maize. Asian J. Agric. and Rural Dev. 3 (5), 296-310.

FAOSTAT (2014) Food and Agricultural Organization of the United Nations (FAO), FAO Statistical Database, 2013, from http://faostat.fao.org. December 2015.

Gomez, K.N. and Gomez, A.A. (1984) "Statistical Procedures for Agricultural Res.", John Wiley and Sons, New York, $2^{\text {nd }}$ ed., p.68.

Khaliq, T., Mahmood, T. and Masood, A. (2004) Effectiveness of farmyard manure, poultry manure and nitrogen for corn (Zea mays) productivity. Inter. J. Agric. Biol. 2, 260-263.

Kumar, B. and Walia, U. S. (2003) Effect of nitrogen and plant population levels on competition of maize (Zea mays L.) with weeds. Indian J. Weed Sci. 35 (1/2), 53-56.

Larbi, E., Ofosu-Anim, J., Norman, J. C., Anim-Okyere, S. and Danso, F. (2013) Growth and yield of maize (Zea mays L.) in response to herbicide application in the coastal savannah ecozone of Ghana. J. Agric. Sci. 1 (3), 81-86.

Maddonni, G.A., Cirilo, A. G. and Otegui, M. E. (2006) Row width and maize grain yield. Agron. J. 98,1532-1543.

Egypt. J. Agron . 38, No.1 (2016) 
Mohamed, S.A. (2004) Efficiency of using abscisic acid and some weed control treatments in controlling associated weeds growth, yield and chemical composition of maize plant. Egypt. J. Appl. Sci. 19 (9B), 452-465.

Moosavi, S.G., Seghatoleslami, M. J. and Moazeni, A. (2012) Effect of planting date and plant density on morphological traits, LAI and forage corn (SC. 370) yield in second cultivation. Inter. Res. J. Appl. Basic Sci. 3 (1), 57-63.

MSTAT-C (1989) MSTAT-C Statistical Program Version 2.10. Crop and Soil Sci. Dept., Michigan State University, USA.

Porter, P., Hicks, D., Lueschen, W., Ford, J., Warnes, D. and Hoverstad, T. (1997) Corn response to row width and plant population in the northern Corn Belt. J. Prod. Agric. 10, 293-300.

Saini, J. P. and Angiras, N. N. (1998) Efficacy of herbicides alone or in mixture to control weeds under mid-hill condition of Himachal Pradesh. India. J. Weed Sci. 30, 65-68.

Saxena, M.C. and Singh, Y. (1965) A note on leaf area estimation of intact maize leaves. Indian J. Agron. 10, 437-439.

Sepahvand, P., Sajedi, N., Mousavi, S. K. and Ghiasvand, M. (2014) Effect of nitrogen application method and weed control on corn yield and yield components. Pak. J. Boil. Sci. 17 (4), 497-503.

Shapiro, C. A. and Wortmann, C.S. (2006) Corn response to nitrogen rate, row spacing and plant density in Eastern Nebraska. Agron. J. 98, 529-535.

Sharara, F. A., El-Shahawy, T. A. and El-Rokiek, K. G. (2005) Effect of some novel herbicides on the controlling weeds associated with maize plants. J. Agron. 4 (2), 8895.

Sharma, A. R., Toor, A.S. and Sur, H.S. (2000) Effect of inter culture operations and scheduling of atrazine application on weed control and productivity of rainfed maize (Zea mays) in Shiwalik foothills of Panjab. India. J. Agric. Sci. 70 (11), 757-761.

Singh, R.P. and Singh, R.K. (2006) Ecological approach in weed management. National Symposium Conservation Agric. and Envi. 25-26 pp.301-305.

Singh, A.P. and Singh, P.C. (2003) Effect of different weed control methods on growth and yield of rabi-sown hybrid maize cv. Hybrid 4640. J. of Living World, 10(2), 1215. 
Tahir, M., Javed, M. R., Tanveer, A., Nadeem, M.A., Bukhari, A.S.A.H. and Jamil-Ur-Rehman (2009)Effect of different herbicides on weeds, growth and yield of spring planted maize (Zea mays L.). Pak. J. Life Soc. Sci. 7 (2), 168-174.

Tamado, T. and Milberg, P. (2000) Weed flora in arable fields of eastern Ethiopia with emphasis on the occurrence of Parthenium hysterophorus L. Weed Res. 40, 507-521.

Teasdale, J. R. (1998) influence of corn (Zea mays) population and row spacing on corn and velvetleaf (Abutilon theophrasti) yield. Weed Sci. 46, 447-453.

Watson, D.J. (1958) The dependence of net assimilation rate on leaf area index. Ann. Bot. Lond. N.S. 22, 37-54.

Widdicombe, W. D. and Thelen, K. D. (2002) Row width and plant density effects on corn grain production in northern Corn Belt. Agron. J. 94, 1020-1023.

Williams, M. K., Heiniger, R. W., Evaerman, W. J. and Jordan, D. I. (2014) Weed control and corn (Zea mays) response to planting pattern and herbicide program with high seeding rates in North Carolina. Advance in Agric. Article 261628, 1-8.

Yong, C. C., HaiPeng, H., Qiang, L., Ping, Z., ZhenYong, Z., ZhiQiang, D. and Ming, Z. (2010) Effects of planting density on photosynthetic characteristics and changes of carbon and nitrogen in leaf of different corn hybrids. Acta Agron. Sinica, 36 (5), 871-878.

Zhang, J., Zheng, L. , Jäck, O., Yan, D., Zhang, Z. and Gerhards, R. (2013) Efficacy of four post-emergence herbicides applied at reduced doses on weeds in summer maize (Zea mays L.) fields in North China plain. Crop Protec. 52, 26-32.

(Received 11/1/2016;

accepted $6 / 3$ /2016) 
تأثثير مقاومة الحشائش والكثافة النباتية في الذرة الثامية

السيد السيد أحمد السبكي و نهال زهدي عبد الباسط النجار قسم المحاصيل ـ كلية الزراعة ـ جامعة الزقازيق ـ الثرقية ـ مصر.

أجريت هذه الدراسة في مركز بحوث التجارب التابع لكلية الزراعة جامعة

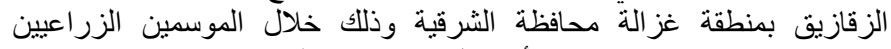

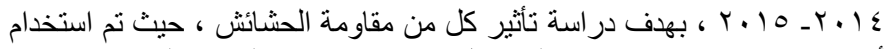

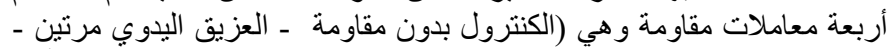

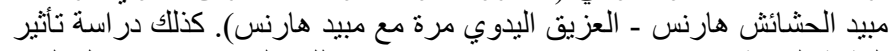

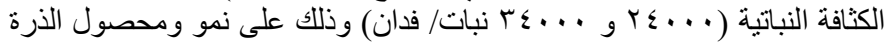

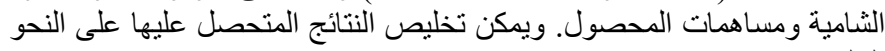

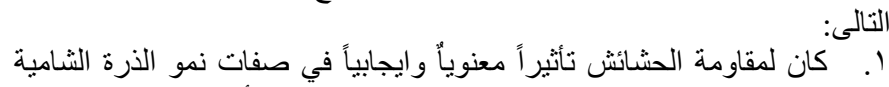

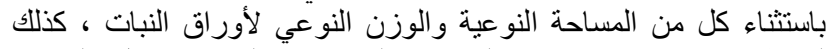

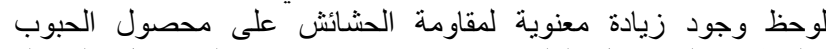

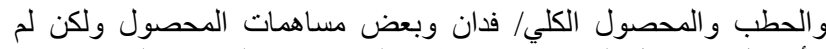
يتأثر كل من طول الكوز ، عدد سطور الكوز وعدان الكوبن الحبوب/ الكوز مقارنة

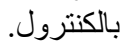

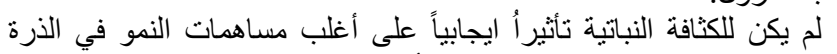

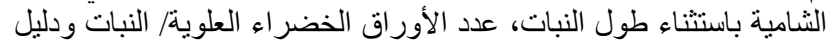

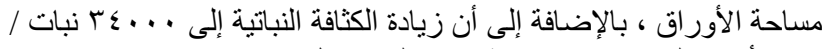

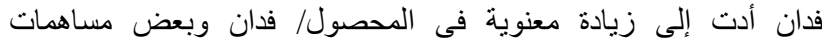

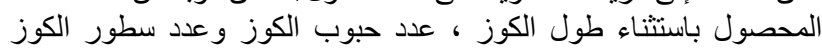

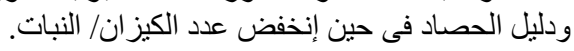

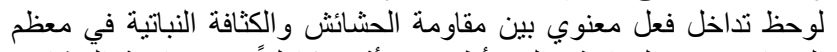

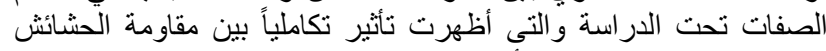

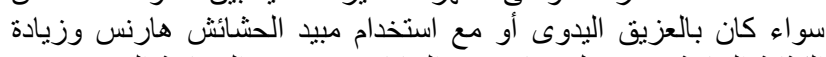

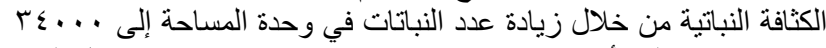

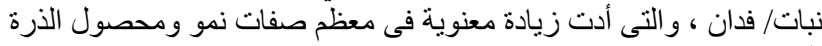

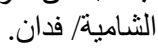

